\title{
Kilka uwag na temat uteoretyzowania podstawowych kategorii dydaktycznych w konstruktywistycznym modelu kształcenia
}

\section{KEYWORDS}

constructivism, didactics, model of education, knowledge

\begin{abstract}
Moroz Jacek, Kilka uwag na temat uteoretyzowania podstawowych kategorii dydaktycznych w konstruktywistycznym modelu kształcenia [A few remarks about the theoretization of basic didactic categories in a constructivist educational model]. Kultura - Społeczeństwo - Edukacja nr 2(14) 2018, Poznań 2018, pp. 63-71, Adam Mickiewicz University Press. ISSN 2300-0422. DOI 10.14746/ kse.2018.14.5.
\end{abstract}

In my article I point to the essential meaning of the "theoretical content" of the accepted educational model. Lack of knowledge of the assumptions, assertions and implications resulting from a given concept or model generates simplifications and becomes the reason of inconsistencies in "didactic thinking" and acting.

The purpose of this article is an attempt to provide justification for the claim about the absolutely theoretized character of considerations (of each type) in the field of education theory. As a consequence, I also put forward a thesis according to which we can not coherently and consistently use concepts such as knowledge and learning "beyond" the paradigmatic context (understood here as a specific theoretical model).

Konstruktywistyczny model kształcenia boryka się z różnymi problemami, często wynikającymi z niejednorodności, a zarazem wielości jego interpretacji. Literatura światowa bogata jest w najrozmaitsze odmiany konstruktywizmu (choć w „polskiej dydaktyce” dostrzega się zazwyczaj dwa, można uznać, że podstawowe jego 
rodzaje: poznawczy i społeczny; pierwszy inspirowany psychologią Jeana Piageta, drugi Lwa Wygotskiego). Denis Philips wyróżnia ich sześć, zauważając, iż nie jest to lista kompletna. Zaproponowany przez niego podział przebiega „wzdłuż” takich nazwisk jak Immanuel Kant, John Dewey, Jean Piaget, Thomas Kuhn, Ernst von Glasersfeld, Linda Alcoff i Elizabeth Potter (Philips, 1995: 6). Nieco inny podział zaproponował David Geelan w artykule Epistemological Anarchy and the Many Forms of Constructivism (Geelan, 1997). Co prawda również w nim odnajdujemy sześć form konstruktywizmu, jednak w tym przypadku autor zastosował inne kryterium demarkacji, wynikiem czego powstała odmienna klasyfikacja. Geelan wyróżnia tak zwany indywidualny konstruktywizm (personal constructivism) Kelly'ego i Piageta, radykalny konstruktywizm Glasersfelda, społeczny konstruktywizm Salomona, społeczny akonstrukcjonizm Gergena, krytyczny konstruktywizm Taylora i kontekstualny konstruktywizm Coberna. W Geelanowskim ujęciu wyraźnie uwidacznia się zasadny w przypadku konstruktywizmu podział na społeczne - indywidualne i obiektywne - relatywne (Geelan, 1997: 20).

\section{I.}

Niezależnie od powyższych rozróżnień konstruktywizm powinno się postrzegać jako projekt interdyscyplinarny, obejmujący swoim zasięgiem wiele, niekiedy bardzo odmiennych w swej metodologii i przedmiocie, badań z zakresu różnych dyscyplin naukowych, począwszy od nauk humanistycznych, tj. filozofii, historii, literaturoznawstwa, przez społeczne - psychologię, pedagogikę, socjologię, a skończywszy na matematyce, informatyce itd. $Z$ tej wielości i różnorodności wyłania się szeroki wachlarz zagadnień obejmujący ogromną różnorodność pól zainteresowań stowarzyszonych z poszczególnymi dyscyplinami naukowymi (por. Moroz, 2015). Z punktu widzenia dydaktyki nie jest oczywiście tak bardzo ważne to, ile konstruktywizmów można wymienić lub jakie cechy im przysługują, niemniej jednak nie można twierdzić, że są to kwestie zupełnie bez znaczenia lub mało istotne dla rozstrzygnięć dydaktycznych. Niekiedy uważa się, że zbyt teoretyczne rozważania są niepotrzebne ${ }^{1} \mathrm{i}$ bez żadnej szkody można je pominąć. Takie podejście jest wyrazem teoretycznej ignorancji i prawdopodobnie jest efektem braku orientacji w założeniach, twierdzeniach i implikacjach wynikających z danej koncepcji, to

\footnotetext{
${ }^{1}$ Bywa, że teoretyczność traktuje się jako niepotrzebny i obciążający (nie tylko praktykę, ale również badania empiryczne) zarazem bagaż. Wydaje się, że nie wszyscy proponenci takiego „rozumienia” nauki są świadomi, że jej „teoretyczna redukcja” pozbawia jej możliwości wydawania sądów (bo eliminuje aparaturę teoretyczną) na temat rzeczywistości (jakkolwiek tę ostatnią rozumieć).
} 
zaś z kolei pociąga za sobą różnego rodzaju pomyłki, generuje uproszczenia i staje się przyczyną niespójności w „dydaktycznym” myśleniu i działaniu.

Wskazany wątek stanowi tło dla problematyki poruszanej w niniejszym artykule, albowiem obrany w nim cel wyraźnie nawiązuje do znajomości szerokich kontekstów dydaktyki, niezbędnych, jak sądzę, dla lepszego rozumienia takich choćby podstawowych zjawisk i procesów, jak wiedza czy uczenie się. Celem niniejszego artykułu jest próba dostarczenia uzasadnienia, choćby „słabego”, dla twierdzenia o bezwzględnie teoretyzowanym charakterze rozważań (każdego typu) z zakresu teorii kształcenia. W konsekwencji stawiam również tezę, zgodnie z którą nie można spójnie i konsekwentnie posługiwać się pojęciami wiedza i uczenie się „poza” kontekstem paradygmatycznym (rozumianym tu jako określony model teoretyczny).

\section{II.}

Jak już wspomniałem, nadmiar podejść konstruktywistycznych stwarza duże możliwości interpretacyjne, co siłą rzeczy prowadzi do wielu nieporozumień. Już sama liczba odmian myślenia konstruktywistycznego może prowokować do pytania o możliwość istnienia tak wielu modeli poznania opartych na jednej tylko fundamentalnej tezie, obowiązującej, skądinąd, dla każdej bez wyjątku wersji konstruktywizmu, jednocześnie stanowiąc warunek i kryterium ich teoretycznej zgodności.

Teza, o której mowa, sprowadza się do pozornie banalnego stwierdzenia, że wiedza jest konstruktem. O ile jest to twierdzenie dla konstruktywizmu fundamentalne, o tyle jego teoretyczne umocowanie ${ }^{2}$, z perspektywy dydaktyki, nie wydaje się wystarczające. W momencie wyartykułowania wskazanej tezy kończą się niejednokrotnie pogłębione rozważania nad jej znaczeniem. Uznaje się, że tak skonstruowana dostarcza zadowalającego wyjaśnienia podstaw konstruktywistycznie rozumianej teorii kształcenia. Pamiętając jednak, że funkcjonujemy w obrębie nauki w istotny sposób „zanurzonej w praktyce”, nie możemy poprzestać jedynie na pobieżnej eksploracji epistemologicznej warstwy konstruktywizmu (choć trzeba wyraźnie podkreślić, iż jest ona dla niego zasadnicza). W tym miejscu wypada postawić kilka wnikliwych pytań: co może oznaczać fraza „konstruowanie wiedzy”? Kto lub co konstruuje? Czy możemy mówić o konstrukcie jako takim? Jeśli nie, to

\footnotetext{
2 Dostępna literatura dydaktyczna zazwyczaj dostarcza dość ogólnikowego wyjaśnienia zagadnienia „wiedzy jako konstruktu”, ograniczając się do kategorii i wyjaśnień z zakresu (nierzadko klasycznej już) psychologii i socjologii wiedzy.
} 
od czego miałby on zależeć? Odpowiedzi istnieją, lecz nie są jednoznaczne. Nawet jeśli nie możemy spodziewać się klarownych i jednoznacznych odpowiedzi, musimy zadawać pytania. Dla dydaktyka bowiem ma znaczenie, czy wiedza to prawdziwe, uzasadnione przekonanie ${ }^{3}$, zbiór informacji, a może nic takiego jak wiedza po prostu nie istnieje, zaś „wiedzieć” to tyle, co reagować na otoczenie (zgodnie $\mathrm{z}$ behawioralnym schematem S-R). Kwestie te mają teoretyczną wagę, która bez wątpienia wyciska swoje piętno na tym, co nie jest już „tylko” modelem, lecz faktycznym działaniem ${ }^{4}$. Podążając tym tropem, musimy zapytać o proces uczenia się - czym on z kolei jest. Trudno jest na to pytanie odpowiedzieć, nie znając odpowiedzi na pytanie, czym jest wiedza, lub jedynie przyjmując założenie (sugerując się wybranymi autorami), że wiedza to bliżej nieokreślony konstrukt. Nie uważam, by te uwagi były jakoś szczególnie odkrywcze, niemniej, pomimo ich „zwyczajności”, w rozważaniach dydaktycznych rzadko widuje się „poważniejsze” odwołania do szeroko pojmowanych badań lingwistycznych, cognitive science, współczesnej psychologii poznawczej itp. To właśnie tam możemy odnaleźć wiele istotnych dla nas koncepcji, choćby, tak istotne z punktu widzenia prowadzonych w dydaktyce badań, współczesne modele umysłu pozwalające w końcu wyjść poza klasyczny (czytaj: przestarzały) już podział na behawioralną koncepcję Black Box i wczesno-kognitywną metaforę umysłu jako maszyny liczącej.

\section{III.}

Problematyka wiedzy, a wraz z nim - poznania jawi się jako wielowarstwowa, a przez to niezwykle skomplikowana. Konstruktywistyczne analizy koncepcji wiedzy „dowodzą”, że to rdzennie filozoficzne zagadnienie można próbować rozstrzygać na polu socjologicznym. Niekiedy uważa się, że jest to możliwe poprzez wyostrzanie akcentów związanych z tak zwanym społecznym tworzeniem rzeczywistości. W takim ujęciu „rzeczywistość” traci swój metafizyczny (a więc bardzo subtelny z uwagi na swoją filozoficzność) sens, stając się społecznie wytwarzanym konstruktem. Takiego zadania podjął się Alfred Schütz, wskazując, że wiedza jednostki o świecie (dla Schütza jest to świat życia codziennego) jest

${ }^{3}$ Kwestię tę poruszałem w artykule Jaka koncepcja wiedzy jest „potrzebna” pedagogice?, argumentując, iż klasyczne pojęcie wiedzy, będąc niepoznawalnym, jest jednocześnie mało „interesującym" dla teoretyka kształcenia (por. Moroz, 2013).

4 To, co nazywam „faktycznym działaniem”, nie może oczywiście być zrozumiałe poza modelem. Opis zawsze jest językowo usytuowany, stąd moje tak duże przywiązanie do „teorii” egzemplifikującej się, za każdym razem, w jakimś modelu. 
podstawowym instrumentem organizowania jej doświadczenia i w żadnym wypadku nie można jej rozumieć jako wiedzy subiektywnej (mimo iż to właśnie nasz jednostkowy umysł wydaje się być podstawowym, a może nawet jedynym jej nośnikiem).

Świat życia codziennego powinien być rozumiany jako świat intersubiektywny, który istniał długo przed naszymi narodzinami i doświadczony oraz interpretowany przez innych naszych przodków - jako świat zorganizowany. Obecnie dany jest naszemu doświadczeniu i interpretacji. Podstawą wszelkiej interpretacji świata jest zasób uprzednich doświadczeń, zarówno naszych własnych, jak i przekazanych nam przez rodziców i nauczycieli który w postaci „wiedzy podręcznej” służą jako schemat odniesienia. (Schütz, 2008: 18)

\section{W innym miejscu Schütz pisze:}

Tak długo, jak działa raz ustalony schemat odniesienia oraz system uzasadnionych doświadczeń naszych i innych ludzi, a także tak długo, jak działania realizowane pod ich kierunkiem dostarczają pożądanych rezultatów, ufamy owym doświadczeniom. (Schütz, 2008: 33)

Również Peter Berger i Thomas Luckmann", stosując analizy socjologiczne, wskazują, że społeczeństwo, w którym żyjemy, jak również język, którym się posługujemy, wyznacza zakres i granice naszej rzeczywistości. Obaj socjologowie, nie wchodząc w subtelną grę analitycznego definiowania zasadniczych dla ich rozważań kategorii wiedzy i rzeczywistości, stwierdzają:

Dla naszych potrzeb wystarczy zdefiniować „rzeczywistość” jako własność takich zjawisk, którym przyznajemy istnienie niezależnie od naszej woli (nie możemy „pozbyć się ich na życzenie), a wiedzę jako pewność, że dane zjawiska są rzeczywiste oraz posiadają określoną charakterystykę. (Berger, Luckmann, 1983: 23)

Takie socjokulturowe stanowisko wspiera w Polsce Andrzej Zybertowicz. Jego zdaniem „(...) o charakterze wiedzy nie przesądza to, co jest jej przedmiotem, ale społeczne okoliczności wytworzenia i funkcjonowania tej wiedzy" (Zybertowicz, 1995: 12). Sama zaś wiedza pojmowana jest bardzo szeroko, jako wszelkie społecznie podzielane przekonania (niezależnie od ich społecznego i epistemologicznego statusu) (por. Zybertowicz, 1995: 19). Dziwić może nieco fakt, że mimo deklaracji o społecznym pochodzeniu wiedzy, a tym samym konwencjonalnym rozstrzyga-

\footnotetext{
${ }^{5}$ Zainspirowani Alfredem Schützem, o czym piszą we wstępie do książki Społeczne tworzenie rzeczywistości (patrz: Berger, Luckmann, 1983).
} 
niu kwestii racjonalności naukowej (a wraz z nią pojęcia wiedzy, prawdy, uzasadnienia itp.), autor pracy „Przemoc i poznanie...” podkreśla, iż można mówić o różnych rodzajach wiedzy w zależności od stopnia jej społecznego zdeterminowania. I tak, zdaniem Zybertowicza, w „skrajnym” przypadku (wiedza matematyczna) wiedzę traktować można jako wolną od wpływów społecznych ${ }^{6}$.

Niezależnie jednak od „kłopotliwego” dla przedstawiciela konstruktywizmu społecznego statusu wiedzy wygenerowanej przez tak zwane nauki ścisłe założenie o metafizycznej naturze świata wydaje się nieprawdopodobne. Odwzorowywanie rzeczywistości przez język (nawet w wersji subtelnej, uwzględniającej jakiś nieoczywisty rodzaj referencji) stwarza spore interpretacyjne problemy i nie wydaje się, by kiedykolwiek stało się możliwe jego racjonalne wyjaśnienie. Warto zaznaczyć, że na konstruktywną rolę języka w kształtowaniu doświadczenia wskazywali francuscy konwencjonaliści już ponad sto lat temu. Wszelkie rozstrzygnięcia empiryczne nie mogłyby mieć miejsca, gdyby nie język i „jego” ustalenia. Nie istnieją teorie - zgodnie z konwencjonalizmem Pierre’a Duhema - które mogłyby być dowiedzione przez doświadczenie, zaś ich uznawalność zależy tylko od decyzji badacza (Jedynak, 2007: 11-14). Z perspektywy sformułowanego w niniejszym artykule celu teza o uteoretyzowaniu obserwacji wydaje się szczególnie „pociągająca”. Głosi ona, że „(...) nie sposób niczego zaobserwować bez wcześniejszych oczekiwań ukształtowanych przez posiadane przez nas teorie” (Grobler, 2006: 7071). Zatem wynikiem przyjętych założeń będzie treść obserwacji, co ostatecznie wpłynie na reakcje obserwatora na otoczenie. Taką holistyczną koncepcję nauki współcześnie reprezentowaną i utożsamianą z Willardem Van Ormanem Quine’m akceptuje Richard Rorty, stwierdzając, że wypływa ona „(...) z przeświadczenia, że uzasadnienie nie jest sprawą jakiejś szczególnej relacji między ideami (czy słowami) a przedmiotami, ale sprawą wymiany poglądów, rzeczą praktyki społecznej” (Rorty, 1994: 153).

Wydaje się więc, że konstruktywizm zdobywa sprzymierzeńców również w filozofii nauki, która podpowiada, że doświadczenie (również to naukowe) ma charakter pewnej konwencji mogącej zostać zinterpretowaną w kategoriach przyjętego języka. Nasze doświadczenie ${ }^{7}$ możliwe jest dzięki poznaniu pojęciowemu (być może nie tylko, niemniej można argumentować, iż jest to dominujący rodzaj poznania). Jednym $z$ warunków poznania pojęciowego, jak słusznie zauważa Zybertowicz, jest komunikacja społeczna, zależna od consensusu. Ten ostatni

${ }^{6}$ Wydaje się, że stwarza to pewne problemy związane z wyjaśnieniem ograniczonej obowiązywalności zasady zdeterminowania społecznego wiedzy. Tej kwestii nie będę dalej rozwijał, albowiem wykracza ona poza przedmiot podjętej w artykule analizy.

${ }^{7}$ Zarówno to naukowe, jak i potoczne, zdroworozsądkowe. 
z kolei nie zależy ani od natury samego języka, ani od metafizycznie pojmowanej rzeczywistości, ani też od własności ludzkiego umysłu (Zybertowicz, 1995: 111). To ustalenie jest znamienne dla naszego wywodu, albowiem z takiej perspektywy zakłada się, że wiedza może być konstruowana jedynie w pewnym określonym, kulturalistycznie pojmowanym systemie poznawczym. Tego ostatniego zatem nie można sprowadzić do jednostkowych, zindywidualizowanych aktów poznawczych - przeciwnie, kultura „sama” niejako wytwarza zasadniczy kontekst dla konstruowanej wiedzy. To wszystko powoduje, że nie jest możliwe przyjęcie poznawczo „uprzywileowanej” pozycji - usytuowanej poza wszelkim dyskursem. Wydając dowolne sądy, oparte na dowolnych spostrzeżeniach bądź obserwacjach, zawsze czynimy to z konkretnego punktu widzenia (możemy nazwać to „perspektywą poznawczą”, „kontekstem poznawczym” „językiem”, „paradygmatem”, „dyskursem” itp.), który, zależnie od użytego terminu czy nazwy, stanowi konglomerat znaków wchodzących ze sobą w ustalone na drodze konwencji relacje, tworząc system komunikacyjny (język). Ten ostatni konstytuuje pewną perspektywę ontologiczną „niewidoczną z innych pozycji”, a takich systemów może być wiele (Moroz, 2014: 21-23).

W takiej perspektywie zagadnienie uczenia się nieomal naturalnie zostaje wpisane w kontekst językowo-społeczny. W konstruktywizmie (znanego mi typu) nikt „na serio” nie będzie głosił koncepcji „światów prywatnych” (choćby dlatego, że, jak wykazał Wittgenstein (2012), język prywatny nie jest możliwy ${ }^{8}$ ). Jak pisze Jeremy Bruner

Konstrukcja rzeczywistości to produkt wytwarzania znaczenia, ukształtowany przez tradycje oraz przez kulturowe narzędzia sposobów myślenia. W tym sensie edukację należy spostrzegać jako wspomaganie młodzieży w uczeniu się użycia narzędzi do wytwarzania znaczeń i konstruowania rzeczywistości w celu lepszego przystosowania do świata, w którym żyje, oraz do rozpoczęcia skutecznego procesu jego modyfikacji zgodnie z własnymi wymaganiami. Edukacja może być nawet rozumiana jako pokrewna doskonalenia architektów lub budowniczych. (Bruner, 2010: 37-38)

Koncepcja edukacji Brunera znajduje się gdzieś pomiędzy podejściem skrajnie socjologicznym a kognitywnym. Jego kulturalizm wyraźnie nawiązuje do badań nad umysłem i językiem ${ }^{9}$. W Kulturze edukacji zaznacza, że przekazywa-

${ }^{8}$ A to właśnie język wyznacza nasze poznawcze pole, tworząc znaną nam ontologię (twierdzenie to jest na tyle subtelne, że należy posługiwać się nim z odpowiednią ostrożnością).

9 Trzeba podkreślić, że wczesne prace Brunera były mocno sytuowane w podejściu poznawczym (por. Bruner, 1978), jednak w jego ostatniej książce (por. Bruner, 2010) wyraźnie nabrały społecznego charakteru. 
nie wiedzy i umiejętności wymaga interakcji w grupie, ponadto „(...) poprzez interakcję z innymi dzieci dowiadują się, czym jest kultura i poznają właściwe jej sposoby konceptualizacji świata" (Bruner, 2010: 38). Niemniej nie sam język stanowi tu zasadniczy motor poznania, lecz intersubiektywność (typowa dla każdego rodzaju konstruktywizmu) pojmowana jako ludzka zdolność rozumienia umysłów innych.

W związku z powyższym wydaje się, iż jedną z najważniejszych kwestii, które musi podnieść konstruktywizm (szczególnie ten dydaktyczny), jest nasza umiejętność czytania „innych umysłów”. Tak więc na pytanie: czym jest wiedza i uczenie się? można odpowiadać w ramach konstruktywizmu, nie tylko powołując się na założenia epistemologiczne i socjologiczne, ale również wskazując na proces jej powstawania, co wymaga zaangażowania nauk kognitywnych. Konstruktywizm wykazuje, jak sądzę, mniejsze zainteresowanie wiedzą jako wytworem, koncentrując się przede wszystkim na jego aspekcie czynnościowym. Wobec powyższego nie jest dobrze, szczególnie dla konstruktywizmu, twierdzić, iż teza o konstruktywnym charakterze wiedzy jest tworem stricte filozoficznym. Można zasadnie twierdzić, iż podstawowa teza konstruktywistyczna znajduje swoje ugruntowanie i uzasadnienie przede wszystkim w naukach o poznawaniu. Jest to kwestia zarazem niezwykle ciekawa, jak i trudna, wymaga bowiem dostarczenia wielu przykładów z zakresu nauk kognitywnych, na to w niniejszym tekście niestety nie ma już miejsca.

Nieumiejętność wpisania się w teoretyczny model opisu zjawisk o naukowej proweniencji jest bolączką nauczycieli (a czasem nawet badaczy) wszystkich szczebli kształcenia zinstytucjonalizowanego (również tych akademickich). W takich przypadkach schematyczne, a niekiedy również chaotyczne myślenie o edukacji zazwyczaj wynika $\mathrm{z}$ braku orientacji w interdyscyplinarnie ujętej problematyce z zakresu teorii kształcenia. Niezrozumienie dla jej szerokich kontekstów wytwarza bardzo szkodliwą, bo teoretycznie zubożałą, praktykę edukacyjną, prowadzącą do niemal całkowitej eliminacji interpretatywnego modelu dydaktyki. Świadomość uteoretyzowania między innymi kategorii wiedzy i uczenia się (a więc zrozumienie, że zyskują one określony sens dopiero w danym języku nauki) stwarza możliwości dla w pełni spójnego myślenia i działania w konstruktywistycznym modelu edukacji, co może się objawić choćby w dobrym rozumieniu aktywnej postawy uczących się, a także nieinterwencyjnej roli nauczyciela funkcjonującego we wskazanym modelu kształcenia. 


\section{Literatura}

Berger P.L., Luckmann T. (1983). Społeczne tworzenie rzeczywistości. Przeł. J. Niżnik. Warszawa.

Bruner J. (1978). Poza dostarczone informacje. Przeł. B. Mroziak. Warszawa.

Bruner J. (2010). Kultura edukacji. Przeł. T. Brzostowska-Tereszkiewicz. Kraków.

Geelan D.R. (1997). Epistemological anarchy and the many forms of constructivism. "Science and Education" vol. 6(1). s. 15-28.

Grobler A. (2006). Metodologia nauk. Kraków.

Jedynak A. (2007). Doświadczenie i język. Warszawa.

Moroz J. (2013). Jaka koncepcja wiedzy jest „potrzebna” pedagogice? „Kwartalnik Pedagogiczny” nr 2, s. $5-20$.

Moroz J. (2014). Czy relatywista może być parezjasta? „Parezja: czasopismo Forum Młodych Pedagogów przy Komitecie Nauk Pedagogicznych PAN” nr 1, s. 21-33.

Moroz J. (2015). Rzeczywistość - poznanie - edukacja w kontekście radykalnego konstruktywizmu Ernsta von Glasersfelda. „Kultura i Edukacja” nr 1(107). s. 71-89.

Philips D.C. (1995). The good, the bad, and the ugly: The many faces of constructivism. "Educational Researcher" vol. 24, no. 7, s. 5-12.

Rorty R. (1994). Filozofia i zwierciadło natury. Przeł. M. Szczubiałka. Warszawa.

Schütz A. (2008). O wielości rzeczywistości. [W:] A. Schütz. O wielości światów. Przeł. B. Jabłońska. Kraków.

Wittgenstein L. (2012). Dociekania filozoficzne. Przeł. B. Wolniewicz. Warszawa.

Zybertowicz A. (1995). Przemoc i poznanie: Studium z nie-klasycznej socjologii wiedzy. Toruń. 
